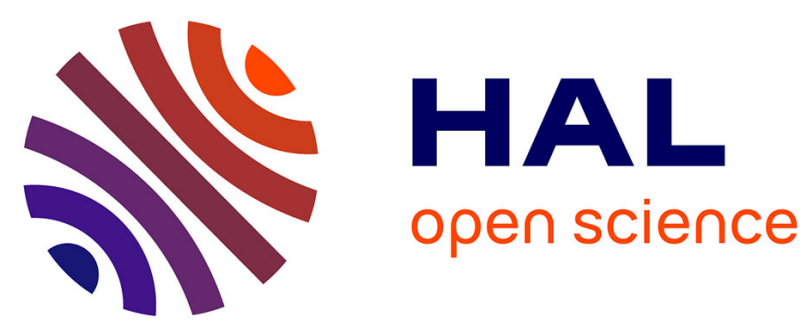

\title{
Full scale tests on grid reinforced flexible pavements on the French fatigue carrousel
}

\author{
Pierre Hornych, Jean Pierre Kerzreho, Armelle Chabot, Stéphane Trichet, \\ Juliette Sohm, Jean-Luc Joutang, Nicolas Bastard
}

\section{To cite this version:}

Pierre Hornych, Jean Pierre Kerzreho, Armelle Chabot, Stéphane Trichet, Juliette Sohm, et al.. Full scale tests on grid reinforced flexible pavements on the French fatigue carrousel. 7th Rilem International Conference on Cracking in Pavements, Jun 2012, France. p. 1251-1260, ill., bibliogr., 10.1007/978-94-007-4566-7_119 . hal-00849431

\section{HAL Id: hal-00849431 \\ https://hal.science/hal-00849431}

Submitted on 31 Jul 2013

HAL is a multi-disciplinary open access archive for the deposit and dissemination of scientific research documents, whether they are published or not. The documents may come from teaching and research institutions in France or abroad, or from public or private research centers.
L'archive ouverte pluridisciplinaire HAL, est destinée au dépôt et à la diffusion de documents scientifiques de niveau recherche, publiés ou non, émanant des établissements d'enseignement et de recherche français ou étrangers, des laboratoires publics ou privés. 


\title{
Full scale tests on grid reinforced flexible pavements on the French fatigue carrousel
}

\author{
Pierre Hornych ${ }^{1}$, Jean-Pierre Kerzrého ${ }^{1}$, Juliette Sohm ${ }^{1}$, Armelle Chabot ${ }^{1}$, \\ Stéphane Trichet ${ }^{1}$, Jean-Luc Joutang ${ }^{2}$, Nicolas Bastard ${ }^{2}$ \\ ${ }^{1}$ LUNAM Université, IFSTTAR, CS4 F-44344 Bouguenais, France - \\ Contact : pierre.hornych@ifsttar.fr \\ ${ }^{2}$ St Gobain Adfors, Viktoriaallee 3-5, 52066 Aachen, Germany
}

\begin{abstract}
Grids are increasingly used. They have proved their efficiency, but there is presently no widely accepted design method to predict the long term life of grid reinforced pavements. This paper describes a full scale experiment carried out on the large pavement fatigue carrousel of IFSTTAR, to test simultaneously 3 pavement sections with different types of grids, in comparison with an unreinforced pavement structure. The tests are carried out on typical French low traffic pavement structures. Results up to approximately 800000 loads are presented. The experiment is planed to continue to load the test sections up to at least 1 million loads. During the experiment, the behaviour of the pavement sections has been followed by deflection and rut depth measurements, and surface distress analysis (observation of cracks and other degradations). As observed on the circular APT for low traffic pavements with thin bituminous layers, crack development was following a transversal orientation. This experiment shows the necessity to better understand the grid behaviour by means of modelling, experiments and use of new measurement techniques as planned in the new Rilem TC-SIB and TC-MCD.
\end{abstract}

\section{Introduction}

Grids are increasingly used, both for reinforcement of existing pavements, and for improving fatigue and reflective cracking resistance of new pavements. These techniques have proved their efficiency, but require attention to achieve a good bonding between the system and the pavement layers during construction. There is presently no widely accepted design method to predict the long term life of grid reinforced pavements. Therefore, full scale tests are needed to evaluate both the construction procedures and the long term performance of these products [1] [2]. 
This paper describes a full scale experiment carried out on the large pavement fatigue carrousel of IFSTTAR in Nantes, to test simultaneously 3 pavement sections with different types of grids, in comparison with an unreinforced pavement structure. The paper presents the construction, instrumentation of the pavements, and the first results of the tests.

\section{Description of the full scale experiment}

The objective of the experiment is to test and compare simultaneously the fatigue behaviour of 4 flexible pavement sections, under typical French axle loading (half axles loaded at 6.5 tons with dual wheels), for a total of 1 million load cycles. The pavement fatigue carrousel of IFSTTAR is a large scale circular outdoor facility, unique in Europe by its size (120 m length, $6 \mathrm{~m}$ width) and loading capabilities (maximum loading speed $100 \mathrm{~km} / \mathrm{h}$, loading rate 1 million cycles per month, 4 arms equipped possibly with different wheel configurations, lateral wandering of the loads to reproduce real traffic) [3].

\section{Test sections and material characteristics}

The tests are carried out on typical French low traffic pavement structures [4] consisting of an $80 \mathrm{~mm}$ thick bituminous wearing course, over a granular subbase (300 mm thick), and a sandy subgrade soil, with a bearing capacity of about 80 $\mathrm{MPa}$. Four structures, each $10 \mathrm{~m}$ long, are tested, representing $1 / 3$ of the whole test track. Structures A and B are reinforced with grids incorporating a special film designed to ensured good bonding and replacing the tack coat. Structure $\mathrm{C}$ is reinforced with a traditional grid with a tack coat. Structure D is a reference structure without reinforcement. The three different grids are placed in the lower part of the bituminous layer, $2 \mathrm{~cm}$ above the interface (Figure 1).

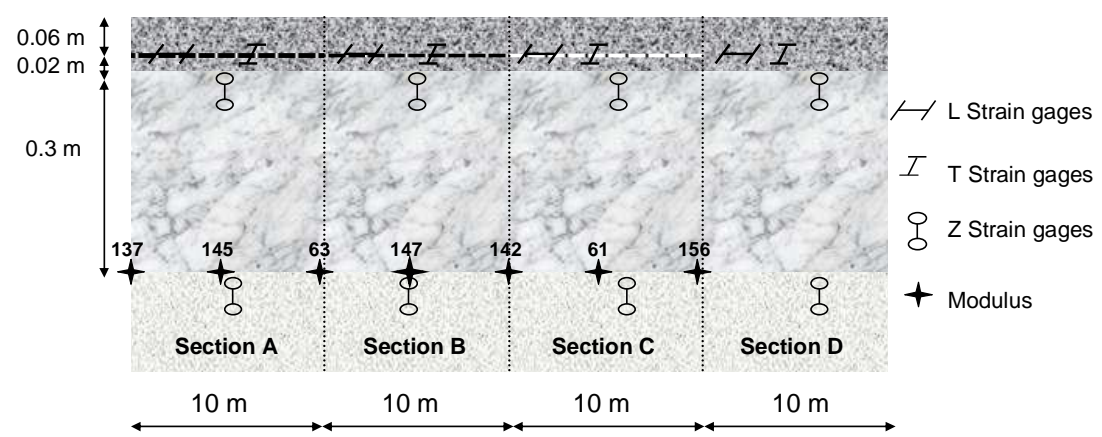

Figure 1. Pavement test sections and implementation of sensors

The bituminous mix is a standard French $0 / 10 \mathrm{~mm}$ wearing course bituminous material, (BBSG 0/10). This material contains $5.5 \%$ of grade $35 / 50$ bitumen. The 
mechanical behaviour of this mix was characterised by classical complex modulus and fatigue tests on trapezoidal specimens (EN 12697-31 and EN 12697-24). The specimens had an average void content of $6.2 \%$. The reference complex modulus of the mix at $15^{\circ} \mathrm{C}$ and $10 \mathrm{~Hz}$ is $11320 \mathrm{MPa}$. The Huet Sayegh viscoelastic model parameters obtained for this mix are presented in Table 1. These parameters can be used for viscoelastic pavement structure calculations [5].

Table 1. Material characteristics

\begin{tabular}{|l|l|l|l|l|l|l|l|}
\hline $\begin{array}{l}\mathrm{E}_{0} \\
(\mathrm{MPa})\end{array}$ & $\begin{array}{l}\mathrm{E}_{\text {inf }} \\
(\mathrm{MPa})\end{array}$ & $\delta$ & $\mathrm{k}$ & $\mathrm{h}$ & $\begin{array}{l}\mathrm{A}_{0} \\
(\mathrm{~s})\end{array}$ & $\begin{array}{l}\mathrm{A}_{1} \\
\left(\mathrm{~s}^{\circ} \mathrm{C}^{-1}\right)\end{array}$ & $\begin{array}{l}\mathrm{A}_{2} \\
\left(\mathrm{~s}^{\circ} \mathrm{C}^{-2}\right)\end{array}$ \\
\hline 10.0 & 27180 & 2.29 & 0.22 & 0.65 & 4.0617 & -0.38792 & 0,0016399 \\
\hline
\end{tabular}

The fatigue law of the mix is approximated by Eqn. (1).

$$
\varepsilon / \varepsilon_{6}=\left(\mathrm{N} / 10^{6}\right)^{\mathrm{b}}
$$

With: $\varepsilon_{6}$, the strain leading to failure for 1 million loads, and $b$, the slope of the fatigue curve. Experimentally, the fatigue parameters obtained for the mix are $\varepsilon_{6}=116 \mu$ strains and $\mathrm{b}=-0.206$.

\section{Characteristics of the tested grids}

The three grids tested are all a high-strength open fiberglass geogrid custom knitted in a stable construction and coated with a patent-pending elastomeric polymer and self-adhesive glue (Tensile Strength: $100 \mathrm{kN} / \mathrm{m} \times 100 \mathrm{kN} / \mathrm{m}$ ). The mesh of grid from test section A is half smaller than those from test section B and C $\left(25 \times 25 \mathrm{~mm}^{2}\right)$. Grids of the test section A and B contain a patent-pending, highly engineered film designed to replace the need for a tack coat. These two new grids have shown a better behaviour during specific 3 point bending fatigue tests [6].

\section{Construction and instrumentation of the test sections}

The pavement structures were built on the existing subgrade of the test track, which is a sand with $10 \%$ fines, sensitive to water. The granular base consisted of $30 \mathrm{~cm}$ of $0 / 31.5 \mathrm{~mm}$ unbound granular material (UGM). After construction, this base was covered by a spray seal. A $2 \mathrm{~cm}$ thick bituminous layer was first laid and compacted on all 4 sections. This layer cooled rapidly down to about $10{ }^{\circ} \mathrm{C}$ (ambient temperature - March 1st, 2011). On sections A and B, the grids were placed without tack coat, due to the adhesive film. On sections C and D (see Figure 2 a-c) a tack coat with $300 \mathrm{~g} / \mathrm{m}^{2}$ of residual bitumen, was applied. Then, longitudinal and transversal strain gauges were put in place (Figure 2.d). The final $6 \mathrm{~cm}$ thick bituminous layer was laid on the 4 sections, and compacted successively with a steel drum vibrating roller and a rubber-tyred roller. To ensure 
melting of the film attached to grids from section $\mathrm{A}$ and $\mathrm{B}$, the bituminous mix was put in place at temperatures above $150^{\circ} \mathrm{C}$. After compaction, the average in situ void content of the mix was about $7.0 \%(0.8 \%$ more than for the specimens tested in the laboratory). The 4 test sections were instrumented with longitudinal and transversal strain gauges placed on the top of the grids (at $6 \mathrm{~cm}$ depth - see Figure 2.d); temperature sensors and vertical strain gauges at the top of the UGM layer and of the subgrade (Figure 1).
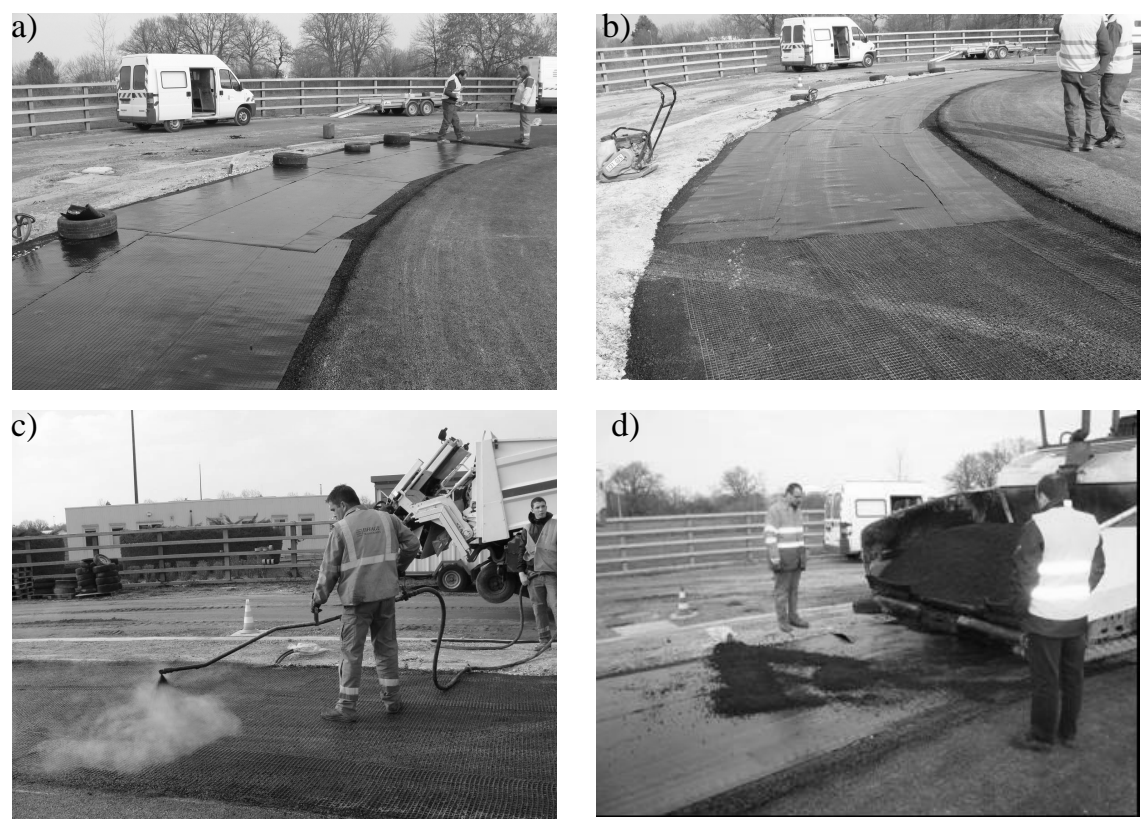

Figure 2. Construction: a) Grids of section A and B ; b) Grids after compaction;

c) Tack coat application; d) Placement of strain gauges before overlay.

The circular shape of the test sections required to cut the grids in relatively narrow bands, $5 \mathrm{~m}$ long by $1.5 \mathrm{~m}$ wide. To cover the test section, one $1.5 \mathrm{~m}$ wide band was placed in the centre of the wheelpath, and then two smaller bands on each side (see figure 2 a). Due to this layout, some construction problems occurred on section A, and potentially on section $\mathrm{B}$, during the laying and compaction of the bituminous overlay, and the results obtained on section A will not be presented. Thorough investigations will be made on section B after completion of the testing to verify the state of the grid and of the interface.

\section{Initial measurements and test programme}

The modulus of the subgrade has been measured with dynamic plate load test and results are shown on Figure 1. These moduli have been measured during 
construction, during a rainy period, and it is probably the reason of their variability. After construction, drainage has taken place, and the bearing capacity has become more homogeneous. Controls after construction have indicated an average thickness of the bituminous layer of $70 \mathrm{~mm}$, instead of $80 \mathrm{~mm}$. The end of section $\mathrm{D}$ is thinner than the other sections, because it is the end of the construction zone, and the transition with another existing pavement structure, which makes the control of the thickness more difficult.

The loading programme started in April 2011. Until September 2011, approximately 800000 loads have been applied. During the experiment, loading has been stopped approximately every 100000 cycles to perform various distress measurements. Response of internal transducers has also been recorded regularly. The ambient temperature conditions were practically constant throughout the tests, with daily temperatures in the range 10 to $28^{\circ} \mathrm{C}$ (mild summer). The rainfall on the test site is presented on Figure 3. It can be noticed that around 600000 cycles, the rainfall level was 2.5 higher than during the other periods.

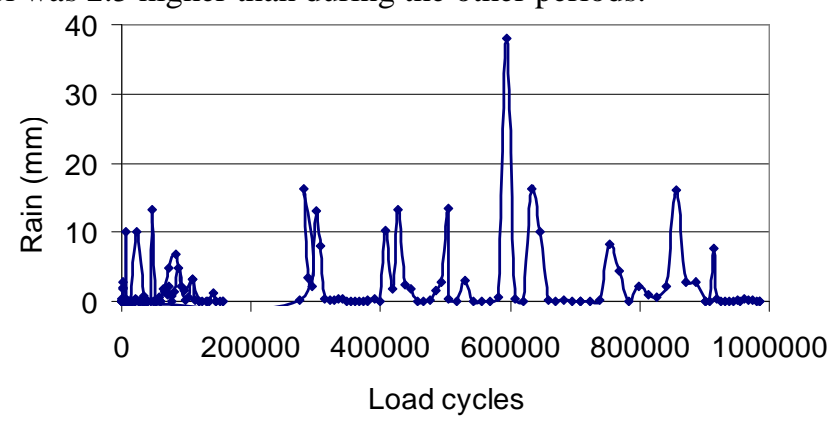

Figure 3. Rainfall measurements on the test site

The four arms of the fatigue carrousel have been equipped with standard dual wheels, loaded at $65 \mathrm{kN}$ (standard French equivalent axle load). The tyres used are Dunlop 1200 R20 SP321, inflated at $850 \mathrm{kPa}$ (Figure 4). The loading speed was 6 rounds $/$ minute $(43 \mathrm{~km} / \mathrm{h})$. Its lateral wandering was $+/-52.5 \mathrm{~cm}$. Between 50000 and 150000 load cycles, one arm was also equipped with a wide single tyre; loaded at 40 or $50 \mathrm{kN}$, in order to compare strain distributions under single and dual tyres. Measurements under the wide single tyre will not be discussed here.
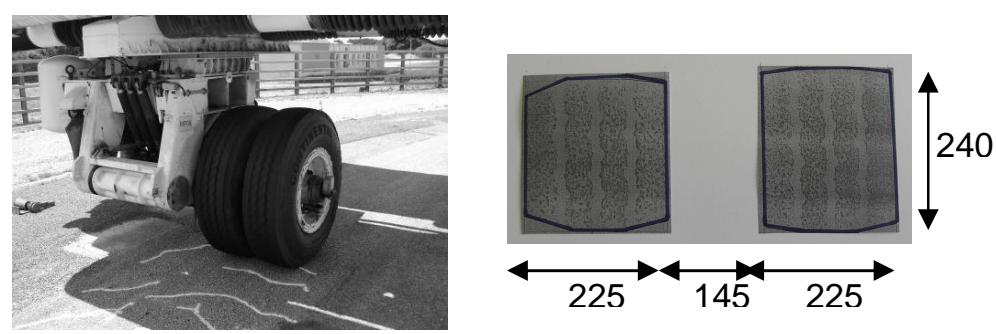

Figure 4. Dual wheel load and its dimensions in $\mathrm{mm}$ 


\section{First results}

\section{Deflection measurements:}

Deflection measurement between the two wheels was performed every 3 meters using a Benkelman beam, under the $65 \mathrm{kN}$ load at about $2 \mathrm{~km} / \mathrm{h}$. For temperatures varying between 20 and $28^{\circ} \mathrm{C}$, Figure 5 shows that up to 381000 load cycles, the mean deflection levels were close to $70 \mathrm{~mm} / 100$ on the three sections with some scatter which may be due to temperature variations. No significant difference in deflection was observed between the reinforced sections $(B, C)$ and the unreinforced section (D). After 537000 load cycles, the mean deflection on section B increased to $83 \mathrm{~mm} / 100$. On sections $\mathrm{C}$ and $\mathrm{D}$, the deflection level remained practically constant up to 813000 loads. There seems to be some relationship between deflection levels and pavement cracking. On section $\mathrm{B}$, the first cracks appeared after 600000 cycles, and simultaneously, an increase of the deflection was observed. On sections $\mathrm{C}$ and $\mathrm{D}$, where very little cracking was observed, the deflections remained constant.

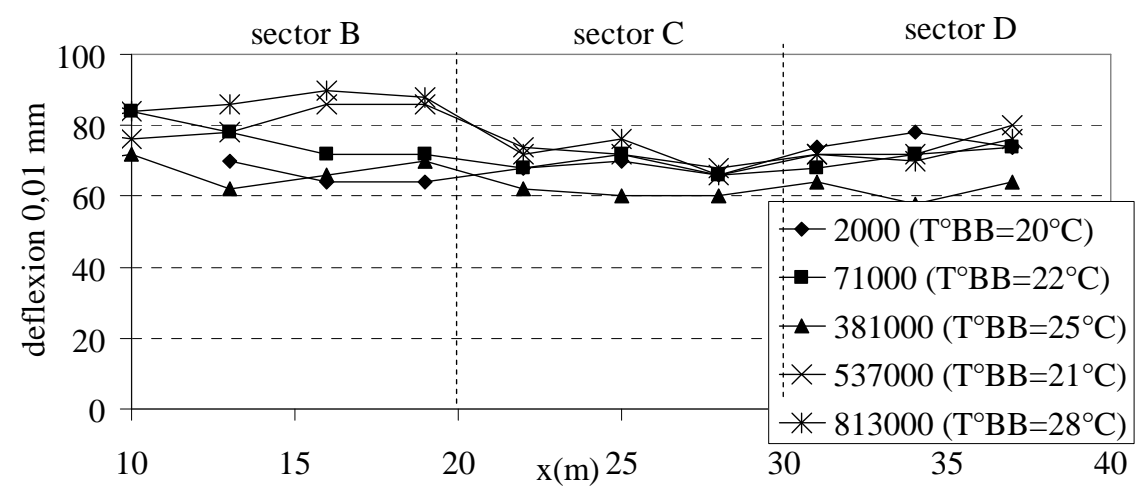

Figure 5. Results of deflection measurements on the 3 sections

\section{Rut depth measurements}

Due to the lateral wandering of the loads, the width of the circulated area is approximately $1.6 \mathrm{~m}$. The transversal profile of the pavement is measured using a 2 meters long ruler, every 3 meters. For each measurement point, the maximum rut depth is determined as the maximum vertical distance between the ruler and the pavement surface. Maximum rut depths measured on the 3 sections, at different load levels are presented on Figure 5. These measurements indicate that, at the beginning, sector B presents a lower rut depth than the other sections, until about 600000 cycles. At this stage, heavy rainfall occurred (Figure 3), and this may explain an increase of the rate of rutting on section B. At, 600000 cycles, section B already presented some cracks (Figure 6), which allowed water to infiltrate in the pavement foundation contrary to the other sections which still presented no 
damage. On sections $\mathrm{C}$ and $\mathrm{D}$, the rut depths are very similar. After 600000 cycles, the evolution of rutting is the same on all 3 sections, with an average final rut depth of $14.3 \mathrm{~mm}$.

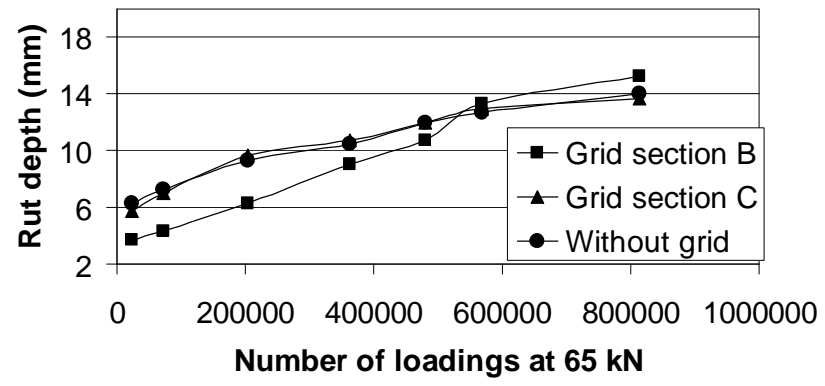

Figure 6. Rut depth evolution on the 3 sections

\section{Crack monitoring}

The first cracks were observed on section B, after about 600000 load cycles, and then on section D after 800000 load cycles. Section C presents no cracking up to now. Crack patterns were very similar on sections B and D: first, very fine isolated transversal cracks appeared. Then, under traffic, these cracks started to open, and fines started to come out. Other thin transversal cracks developed nearby. The transversal orientation of the cracks is typical of fatigue cracking observed on the carrousel, for pavements with thin bituminous layers [7]. Figure 7 presents the evolution of the extent of cracking, as a function of the level of traffic. It corresponds to the percentage of the length of the pavement affected by cracks (for a transversal crack, the affected length is considered, arbitrarily, to be $500 \mathrm{~mm}$ ).

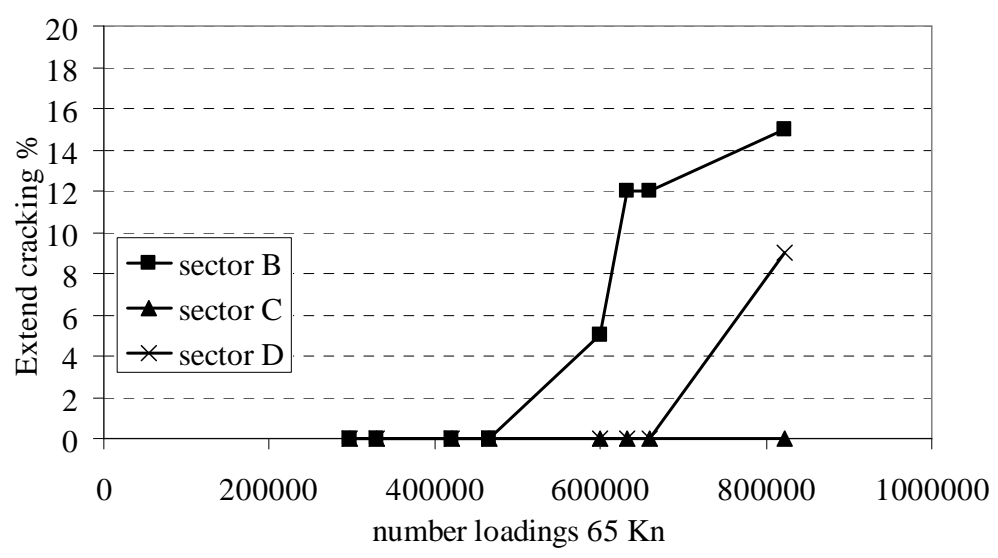

Figure 7. Extent of cracking, in percent, on the 3 sections 


\section{Strain measurements}

Longitudinal and transversal strain measurements, for a temperature of about $20^{\circ} \mathrm{C}$ (at $40 \mathrm{~mm}$ depth) and a loading speed of $43 \mathrm{~km} / \mathrm{h}$, are presented on Figure 8 . On section $\mathrm{C}$, no measurements are available because the strain gauges were broken during the compaction. The sensors were located in the middle of the wheel path, at position $\mathrm{y}=0 \mathrm{~mm}$, and their measurements were recorded for different lateral positions of the dual wheels, varying between -550 and $+550 \mathrm{~mm}$. Positions $\mathrm{y}=-$ $210 \mathrm{~mm}$, and $+210 \mathrm{~mm}$ correspond to the situation when the centre of one wheel is located on the top of the sensors (Figure 4).

a)

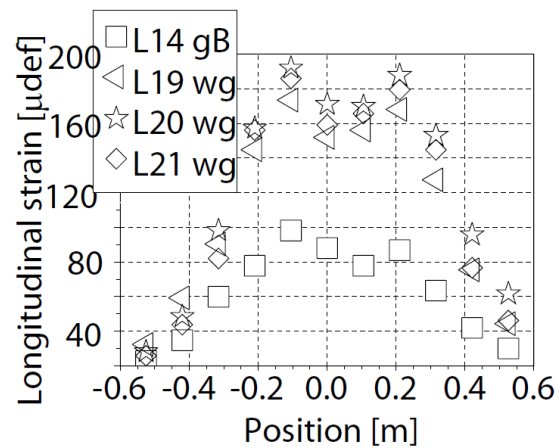

c)

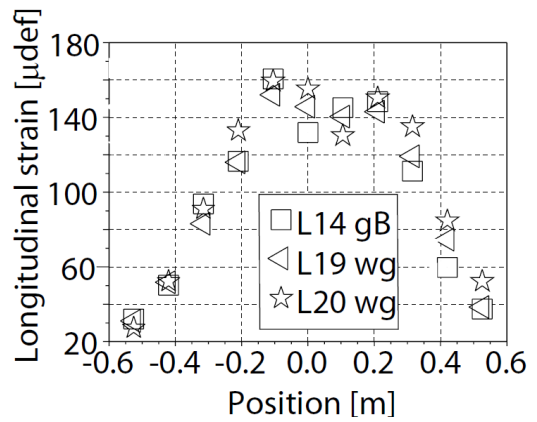

b)

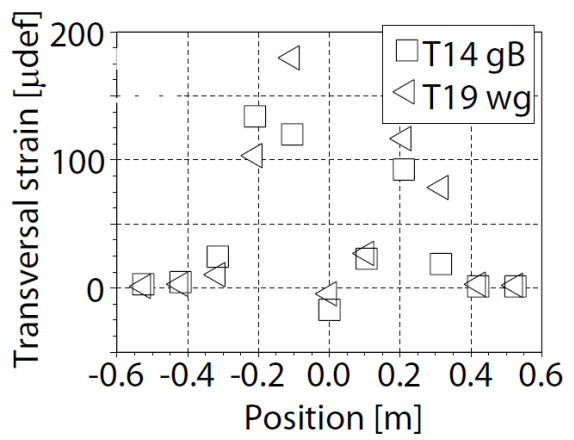

d)

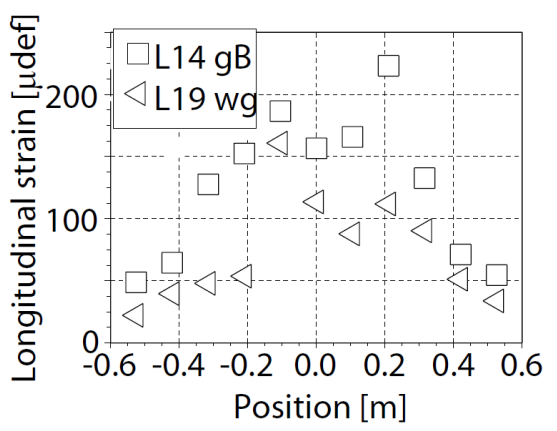

Figure 8. Maximum longitudinal $\varepsilon_{\mathrm{L}}$ and transversal $\varepsilon_{\mathrm{T}}$ strains measured: a) and b): $\varepsilon_{\mathrm{L}}$ and $\varepsilon_{\mathrm{T}}$ at 12000 cycles, $19.2^{\circ} \mathrm{C}$; c) $\varepsilon_{\mathrm{L}}$ at 152000 cycles, $21.1^{\circ} \mathrm{C}$;

d) $\varepsilon_{\mathrm{L}}$ at 676000 cycles, $21.6^{\circ} \mathrm{C}$

At the beginning of the test, at 12000 cycles, (Figure $8 \mathrm{a}-\mathrm{b}$ ), longitudinal strains measured on section $\mathrm{B}(\mathrm{gB})$ (gauge L14) are around half the longitudinal strains measured on section D without grid (wg) (gauges L19, L20, L21). For transversal strains, there is no clear difference between the measurements on section B (gauge T14) and on section D without grid (gauge T19). On section D, longitudinal and 
transversal strains are of the same level of magnitude. On the reinforced section, longitudinal strains are lower.

At 152000 (Figure 8.c), the longitudinal strains on sections B have increased and they are similar to those on section D without grid. At 676000 cycles (Figure $8 \mathrm{~d}$ ), the longitudinal strains measured on section B are greater than those measured on section D. The same trend is observed for the deflection (Figure 5), which is higher on section B, after 530000 cycles, than on section D. This increase of the strains and deflection can be due to the development of cracks as shown on Figure 7. For transversal strains, no significant evolution is observed at the different load levels, and the response of sections B and D remains similar.

Elastic back calculations have been made to estimate the moduli of the unbound granular material and of the soil from deflection measurements. The ALIZE design software used is based on Burmister's multi-layer linear elastic model [8]. Simulations have shown that the soil modulus is $80 \mathrm{MPa}$. According to the French pavement design method, the modulus of the unbound granular materials has been taken equal to $200 \mathrm{MPa}$ (modulus of the soil multiplied by 2.5). The longitudinal strains $\varepsilon_{\mathrm{L}}$ and transversal strains $\varepsilon_{\mathrm{T}}$ calculated under the centre of the dual wheel axle (position y $=0$ ) are respectively $\varepsilon_{\mathrm{L}}=89 \mu \mathrm{def}$ and $\varepsilon_{\mathrm{T}}=15 \mu \mathrm{def}$. These results are of the same order of magnitude as the strains measured at the start of the experiment, on section B. After a significant level of traffic, the measured strains increased on section $\mathrm{B}$, indicating a probable deterioration of this section, due to traffic.

\section{Conclusion}

In this experiment, several different grids were tested as reinforcement of new pavements, with relatively thin bituminous layers $(80 \mathrm{~mm})$; the objective was to compare the behaviour of the reinforced sections, in comparison with a reference section without grid.

During construction, there were some difficulties to place the grids on the circular test track, which obliged to cut the grids in relatively narrow bands. Due to this layout, some construction problems, leading possibly to debonding of the reinforced layer, occurred on section B.

Concerning the behaviour of the pavements, it was found that:

- Cracking appeared first on section B after a rainy period, after around 60000 cycles, and section D (without grid) after 800000 cycles. Section C presents no cracking up to now. The worse performance of section B may be related with the construction problems.

- Rutting was somewhat lower on section B up to 600000 cycles, and after that, the levels of rutting were very similar on the 3 sections;

- Strain measurements indicated lower longitudinal strains on the reinforced sections at the beginning of the experiment, but this difference disappeared after about 150000 cycles, leading to similar deformations on all sections. 
As the experiment is not finished, it is only possible to conclude that a positive effect of the grids on the resistance to cracking is observed on one section (C). It is planned to continue the loading until at least 1 million loads, in order to attain higher levels of damage, and confirm the differences between the 3 tested sections. At the end of the experiment, detailed investigations (cores, trenches, FWD) will be made to understand the possible cracking scenarios, and explain the behaviour of section B in particular, which may be due to debonding problems.

These observations, as those reported elsewhere [9-10-11], will also be completed by means of additional modelling, and non destructive testing, in relation with the two new Rilem Technical committees TC-SIB (TG4 - Advanced interface Testing of Geogrids in Asphalt Pavements) and TC MCD (Mechanisms of Cracking and Debonding in asphalt and composite pavements) in TG 3 on "Advanced Measurement Systems for Crack Characterization"

\section{References}

[1] Antunes, M-L. Dommelen, A.Van Sanders, P. Balay, J-M. Gamiz, E-L (2004), In: Cracking in Pavements, Proc. of the 5th Int. RILEM Conf., pp. 45-52, Petit, C. Al.-Qadi, IL Millien, A. (Eds), Rilem Editions, Paris.

[2] Kerzrého, J.P. Michaut, J.P. Hornych, P. (2011), Revue Générale des Routes et aérodromes, n. 890 , pp. 48 - 51.

[3] Autret, P. de Boissoudy, A.B. \& Gramsammer, J.C. (1987), In Proc. of the 6th Int. Conf. on Struct. Design of Asphalt Pavements, vol. 1, pp. 550-561.

[4] Corte, J.F. Goux, M.T. (1996), TRR, vol. 1539, p.116-124.

[5] Chabot, A. Chupin, O. Deloffre, L. Duhamel, D. (2010), RMPD, vol.11, n. 2 (Special Issue on Recent Advances in Num. Simul. of Pavements), pp. 227-250.

[6] http://www.sg-adfors.com/Brands/GlasGrid

[7] Hornych, P. Kerzreho, JP. Chabot, A. Bodin, D. Balay, J.-M. Deloffre, L. (2008). In: Pavement Cracking, Proc. of the 6th Int. RILEM Conf., pp. 671-681, Al-Qadi, Scarpas and Loizos (Eds), CRC Presse.

[8] http://www.lcpc.fr/en/produits/alize/index.dml

[9] Florence, C. Foret, G. Tamagny, P. Sener, JY. Ehrlacher, A. (2004). In: Cracking in Pavements, Proc. of the 5th Int. RILEM Conf., pp. 605-612, Petit C. Al-Qadi, IL. Millien, A. (Eds), Rilem Editions, Paris.

[10] Perez, S.A. Balay, J.M. Petit, C. Tamagny, P. Chabot, A. Millien, A. Wendling L. (2008). In: Pavement Cracking, Proc. of the 6th Int. RILEM Conf., pp. 55-65, Al-Qadi, Scarpas and Loizos (Eds), CRC Presse.

[11] Graziani, A. Virgili, A. Belogi, L. (2011). In Proc. of the 5h Int. Conf. bituminous mixtures and pavements, Thessaloniki, Greece. 